\title{
PEMANFATAAN MEDIA POWTOON UNTUK MENINGKATKAN SEMANGAT DAN HASIL BELAJAR EKONOMI SISWA KELAS XI IPS 1 SMA NEGERI 6 TEBO
}

\author{
ROHENAN \\ SMA Negeri 6 Tebo, Provinsi Jambi \\ Email : drsrohenan@gmail.com
}

\begin{abstract}
ABSTRAK
Penelitian ini bertujuan untuk: mendeskripsikan pemanfaatan media powtoon untuk meningkatkan hasil belajar mata pelajaran ekonomi materi sistem perekonomian Indonesia pada siswa kelas XI IPS 1 SMA Negeri 6 Tebo Provinsi Jambi tahun pelajaran 2018/2019. Penelitian ini merupakan Penelitian Tindakan Kelas (PTK) yang terdiri atas 2(dua) siklus. Setiap siklus terdiri atas tahap perencanaan, pelaksanaan tindakan, pengamatan (observasi) dan refleksi. Subyek penelitian ini adalah seluruh siswa kelas kelas XI IPS 1 SMA Negeri 6 Tebo yang berjumlah 35 siswa. Teknik pengumpulan data meliputi observasi, wawancara, tes, dan dokumen. Teknik analisis data menggunakan analisis deskriptif kualitatif. Hasil penelitian menunjukkan bahwa rata-rata nilai hasil belajar siswa pada siklus I sebesar 77,28 dengan ketuntasan klasikal sebesar 60\%, meningkat menjadi 81,42 dengan ketuntasan klasikal $85,71 \%$ pada siklus II. Pemanfaatan media powtoon dapat meningkatkan hasil belajar siswa kelas kelas XI IPS 1 SMA Negeri 6 Tebo pada mata pelajaran ekonomi materi sistem perekonomian Indonesia semester genap tahun pelajaran 2018/2019.
\end{abstract}

Kata Kunci: Pemanfaatan, media powtoon, hasil belajar, sistem perekonomian Indonesia.

\section{PENDAHULUAN}

Perkembangan jaman yang semakin modern terutama pada era globalisasi seperti sekarang ini menuntut adanya sumber daya manusia (SDM) yang berkualitas tinggi. SDM yang berkualitas merupakan modal dasar sekaligus kunci dari keberhasilan pembangunan. Hal ini karena dalam segala bidang pembangunan membutuhkan SDM yang berkualitas agar mampu menguasai perkembangan ilmu pengetahuan dan teknologi yang semakin maju. Salah satu sarana untuk meningkatkan kualitas SDM tersebut adalah melalui pendidikan (Sunardi, 2013: 3).

Salah satu bidang keilmuan yang penting dalam bidang kehidupan adalah Ekonomi. Ekonomi merupakan bidang kajian yang mempelajari tentang aktivitas manusia dalam memenuhi kebutuhannya yang tidak terbatas dan selalu berkembang. Pelajaran ekonomi di SMA merupakan mata pelajaran yang wajib ditempuh oleh semua siswa jurusan IPS seluruhnya. Tujuan diajarkan ekonomi di SMA yaitu untuk membekali siswa agar mampu memahami dan menerapkan konsep ekonomi sebagai pedoman dalam berperilaku secara ekonomi, sehingga siswa mampu memecahkan permasalahan dan peristiwa yang terjadi dalam kehidupan sehari-hari. Kegiatan pembelajaran ekonomi di kelas berisi proses komunikasi yang dilakukan oleh guru dan siswa, dimana guru yang menentukan arah komunikasi yang terjadi. Guru terlebih dahulu merancang rencana pelaksanaan pembelajaran (RPP), mementukan dan membuat media yang akan digunakan, menentukan metode pembelajaran yang sesuai dengan materi ajar dan lainnya. Penelitian dilakukan di SMA Negeri 6 Tebo karena peneliti melihat adanya permasalahan semangat belajar siswa yang masih rendah pada mata pelajaran ekonomi. Permasalahan inilah yang masih dihadapi pada mata pelajaran IPS di kelas XI IPS 1. Hal tersebut berimbas pada hasil belajar siswa kelas XI IPS 1 SMA Negeri 6 Tebo yang tergolong masih rendah pada mata pelajaran ekonomi.

Dijelaskan bahwa Hasil belajar merupakan akibat dari proses belajar seseorang. Secara umum dapat didefenisikan bahwa hasil belajar merupakan penilaian diri siswa (Young, Klemz, \& Murphy, 2003), dan perubahan yang dapat diamati, dibuktikan, dan terukur dalam kemampuan atau prestasi yang dialami oleh siswa sebagai hasildari pengalaman belajar (Nemeth \& Long, 2012). Proits mengungkapkan bahwa hasil belajar dapat menggambarkan 
kemampuan siswa setelah apa yang mereka ketahui dan pelajari (Molstad \& Karseth, 2016). Hasil belajar terkait dengan perubahan pada diri orang yang belajar. Bentuk perubahan sebagai hasil dari belajar berupa perubahan pengetahuan, pemahaman, sikap dan tingkah laku, keterampilan dan kecakapan. Perubahan dalam arti perubahan-perubahan yang disebabkan oleh pertumbuhan tidak dianggap sebagai hasil belajar. Perubahan sebagai hasil belajar bersifat relatif menetap dan memiliki potensi untuk dapat berkembang (Lestari, 2015).

Berdasarkan hal tersebut dan adanya dukungan dari pihak sekolah untuk menerima peneliti melakukan penelitian serta adanya kemauan guru untuk mengatasi permasalahan pembelajaran dengan melakukan perbaikan, maka di harapkan permasalahan tersebut dapat teratasi.

Hasil observasi awal menunjukkan hasil belajar siswa pada mata pelajaran ekonomi di kelas XI IPS 1 SMA Negeri 6 Tebo paling rendah dari kelas lainnya, yaitu dengan skor ratarata hasil belajar mencapai 2,45 (rendah). Skor rata-rata hasil belajar siswa dapat diukur dari, partisipasi, nilai tugas, nilai ujian tengah semester dan nilai rapor ujian akhir semester siswa selama pembelajaran berlangsung. Hasil belajar materi ekonomi adalah hasil yang diperoleh melalui sebuah kegiatan belajar materi ekonomi secara mandiri untuk mengetahui seberapa jauh tujuan pembelajaran telah tercapai. Dalam kenyataannya tidak mudah bagi siswa memperoleh hasil belajar materi ekonomi yang memuaskan seperti yang diharapkan (Chulsum, 2017: 5-20). Hasil belajar ditandai dengan dengan perubahan tingkah laku. Perubahan tingkah laku pada kebanyakan hal merupakan sesuatu perubahan yang dapat diamati (observable) (Prayuda, Thomas, Basri, 2014: 8).

Dari hasil wawancara dengan siswa kelas XI IPS 1 SMA Negeri 6 Tebo, permasalahan di kelas XI IPS 1 SMA Negeri 6 Tebo ini disebabkan oleh beberapa faktor antara lain guru masih memakai media pembelajaran yang biasa, yaitu power point. Power point yang digunakan kurang menarik karena hanya menampilkan materi saja sehingga siswa kurang aktif dalam pembelajaran di kelas. Guru perlu menggunakan media pembelajaran yang bervariatif agar dapat meningkatkan semangat belajar siswa dalam proses belajar di kelas XI IPS 1 SMA Negeri 6 Tebo. Karena salah satu faktor yang mempengaruhi hasil belajar siswa adalah kemampuan guru dalam melaksanakan kegiatan pembelajaran. Kegiatan pembelajaran yang optimal dan hasil belajar siswa yang baik merupakan harapan semua pihak namun kenyataan di lapangan masih menunjukkan kegiatan guru yang bekerja kurang optimal dan masih dijumpai hasil belajar siswa yang di bawah KKM cukup banyak (Syaidah, Suyadi, Ani, 2018: 185).

Penggunaan media yang bervariasi akan menimbulkan semangat siswa dalam belajar. Semangat merupakan suatu sifat yang cenderung mendorong diri seseorang untuk melakukan sesuatu yang ingin dicapai. Semangat besar sekali pengaruhnya terhadap belajar. Siswa yang mempunyai semangat yang tinggi, akan menaruh perhatian dan kekuatan yang lebih terhadap pelajaran (Kartika, 2014). semangat besar pengaruhnya terhadap belajar, karena bila bahan pelajaran yang dipelajari tidak sesuai dengan minat siswa, maka siswa tidak akan belajar dengan sebaik-baiknya karena tidak ada daya tarik baginya. Ia akan enggan dan tidak memiliki upaya untuk belajar, ia tidak memperoleh kepuasan dari pelajaran itu. Sebaliknya bahan pelajaran yang menambah semangat siswa, lebih mudah dihafalkan dan disampaikan, karena semangat mengikuti kegiatan belajar. Dengan demikian dapat disimpulkan bahwa semangat belajar anak yang tinggi pada akhirnya akan mencapai hasil belajar yang memuaskan (Pangestu \& Tiya, 2015: 17).

Usaha yang dapat dilakukan untuk menumbuhkan semangat belajar siswa adalah mengetahui kebutuhan siswa, memberikan pelayanan yang optimal terhadap keperluan siswa, memberikan informasi pada siswa mengenai hubungan antara suatu bahan pelajaran yang akan diberikan dengan bahan pelajaran yang lalu, menguraikan kegunaannya bagi siswa dimasa yang akan datang, dan memberikan insentif dalam usaha mencapai tujuan pembelajaran (Hermawati, 2012). Pembelajaran akan lebih menarik jika media 
pembelajaran tersebut benar-benar disiapkan untuk memenuhi kebutuhan dan kemampuan siswa sehingga siswa dapat aktif berpartisipasi dalam proses belajar mengajar.

Penggunaan media pembelajaran yang sesuai dalam proses belajar mengajar dapat membangkitkan motivasi dan rangsangan kegiatan belajar yang berasal dari dalam diri siswa tersebut. Siswa yang memiliki kemauan belajar yang tinggi akan bersungguh-sungguh dan bersemangat dalam belajar untuk mencapai tujuan yang diinginkan dan sebaliknya siswa yang memiliki semangat belajar rendah cenderung malas untuk belajar. (Widiasih, Widodo, Kartini, 2018: 103-107).

Oleh karena itu, atas dasar berbagai faktor yang telah dikemukakan di atas, maka peneliti akan mencoba memberikan suatu bentuk upaya dalam pemecahan berbagai permasalahan tersebut yaitu, peneliti akan mencoba membuat sebuah media pembelajaran berbasis teknologi informasi dan komunikasi (TIK) yang lebih menarik dan lebih modern dengan menggunakan perangkat lunak Powtoon yang merupakan suatu perangkat lunak pengolah media presentasi animasi berbasis SaaS (Software as a Service) yang dapat diakses secara online melalui situs $w w w$.powtoon.com yang dapat digunakan sebagai alat bantu presentasi bagi guru dalam melaksanakan proses pembelajaran di dalam kelas (Fajar, 2017).

Media pembelajaran yang tepat untuk mengatasi permasalahan tersebut adalah media pembelajaran Powtoon. Dengan menggunakan media Powtoon diharapkan semangat dan hasil belajar siswa bisa meningkat. Powtoon merupakan program aplikasi bersifat online yang ada di internet dan berfungsi sebagai aplikasi pembuat video untuk presentasi maupun media pembelajaran. Kelebihan yang dimiliki oleh powtoon yakni mudah digunakan karena hasil akhirnya berupa video serta kemudahan membuat animasi-animasi yang dapat menarik minat siswa (Adkhar, 2015). Powtoon merupakan program aplikasi yang bersifat online yang ada di internet dan berfungsi sebagai aplikasi pembuat video untuk presentasi maupun media pembelajaran. Peneliti menggunakan media Powtoon tersebut untuk diterapkan di SMA Negeri 6 Tebo sebagai media pembelajaran untuk lebih menarik semangat siswa dalam pembelajaran khususnya pada siswa-siswi kelas XI IPS 1 SMA Negeri 6 Tebo Media ini akan menumbuhkan semangat siswa, dan meningkatkan hasil belajar siswa.

Ada penelitian yang sejenis yang dijadikan acuan bagi peneliti untuk melakuakan penelitian ini. Penelitian yang dilakukan peneliti sebelumnya oleh Khamid Faujan Zumroni (2015) dengan judul "Penggunaan Media Powtoon dalam Pembelajaran Sejarah untuk Meningkatkan Hasil Belajar Siswa Kelas X IPS 1 SMA Negeri 1 Slahung Ponorogo" dan Penelitian sejenis selanjutnya dilakukan oleh Maria Virginingsih (2011) dengan judul "Penggunaan Media Audio Visual Untuk Meningkatkan Semangat dan Hasil Belajar Siswa".

Media pembelajaran Powtoon merupakan salah satu media pembelajaran berbasis audio dan visual. Menurut Khamid (2015) "Powtoon merupakan salah satu jenis layanan online yang memiliki fitur animasi yang menarik dalam penyampaian pesan berupa video. Ini adalah salah satu alternatif dari berkembangnya teknologi untuk digunakan media pembelajaran interaktif pada materi yang dianggap sulit menjadi lebih menyenangkan karena disajikan dengan kombinasi beberapa media seperti audio dan visual. Oleh karena itu media ini sangatlah menarik untuk digunakan di dalam kelas sebagai alternatif media pembelajaran agar siswa tidak bosan dengan pembelajaran selain itu juga membuat media pembelajaran guru lebih bervariatif".

Menurut Jihad dkk (2012:14), hasil belajar adalah pencapaian bentuk perubahan tingkah laku siswa secara nyata setelah dilakukan proses belajar mengajar yang sesuai dengan tujuan pengajaran yang cenderung menetap dari ranah kognitif, afektif dan psikomotor. Setelah melalui proses belajar maka siswa diharapkan dapat mencapai tujuan belajar yang disebut juga sebagai hasil belajar. Tujuan belajar adalah sejumlah hasil belajar yang menunjukkan bahwa siswa telah melakukan perbuatan belajar, pengetahuan, keterampilan dan sikap-sikap yang baru, yang diharapkan dapat dicapai oleh siswa.

Peranan penggunaan media pembelajaran Powtoon dapat membuat siswa lebih memahami pelajaran dan membangkitkan semangat belajar. Dengan suasana pembelajaran 
yang menarik perhatian, maka siswa dapat mempengaruhi semangat belajar siswa sehingga dapat meningkatkan hasil belajar siswa.

Berdasarkan penelitian di atas, maka hipotesis dalam penelitian ini adalah penggunaan media pembelajaran Powtoon dapat meningkatkan semangat siswa dan penggunaan media pembelajaran Powtoon dapat meningkatkan hasil belajar siswa.

\section{METODE PENELITIAN}

Penelitian ini merupakan penelitian tindakan kelas (PTK) yang dilaksanakan di kelas XI IPS 1 SMA Negeri 6 Tebo Kecamatan VII Koto Kabupaten Tebo Provinsi Jambi sebanyak 2 (dua) siklus. Subyek penelitian ini adalah seluruh siswa kelas XI IPS 1 sebanyak 35 siswa. Teknik pengumpulan data dalam penelitian ini menggunakan metode observasi, wawancara, tes, dan dokumen. Metode analisis data menggunakan analisis deskriptif kualitatif. Prosedur penelitian tindakan kelas ini setiap siklusnya terdiri atas empat kegiatan yaitu: 1) Perencanaan, sebelum mengadakan penelitian peneliti menyusun rumusan masalah, tujuan dan membuat rencana tindakan, termasuk di dalamnya intrumen penelitian dan perangkat pembelajaran. 2) Tindakan dan pengamatan atau observasi, meliputi tindakan yang dilakukan oleh peneliti sebagai upaya membangun pemahaman konsep peserta didik serta mengamati hasil atau dampak dari penggunaan media pembelajaran Powtoon. 3) Refleksi, Tahap refleksi diperlukan untuk mengkaji serangkaian kegiatan yang telah dilakukan sebelumnya. Pengkajian kembali dapat digunakan peneliti untuk mengetahui kegiatan yang telah dicapai dan yang belum dicapai pada saat pelaksanaan tindakan dan observasi. 4) Rencana perbaikan, Kegiatan yang dilaksanakan pada tahap perencanaan pada siklus II, berdasarkan refleksi dari siklus I, diperoleh data mengenai kekurangan-kekurangan yang terjadi pada siklus I yang merupakan acuan untuk melaksanakan tindakan perbaikan pada siklus II agar hasil tindakan yang dicapai lebih optimal.

\section{HASIL DAN PEMBAHASAN}

Penelitian ini dilaksanakan sebanyak dua siklus, setiap siklus terdiri dari dua pertemuan. Pada siklus I guru sudah menggunakan media Powtoon dengan baik meskipun masih ada beberapa kendala yang disebabkan karena media Powtoon merupakan media yang masih baru pertama kali digunakan di kelas XI IPS 1. Kendala yang dihadapi pada siklus I dapat diperbaiki pada siklus II, sehingga pada siklus II pembelajaran dengan menggunakan media pembelajaran Powtoon berjalan dengan lancar dan sesuai perencanaan yang sudah dibuat pada RPP. Adapun skor semangat belajar siswa pada siklus I dan siklus II terlihat dalam tabel 1 berikut.

Tabel 1. Rata-rata Semangat Belajar Siswa kelas XI IPS 1 SMA Negeri 6 Tebo

\begin{tabular}{clcccc}
\hline No & \multicolumn{1}{c}{$\begin{array}{l}\text { Indikator Semangat Belajar } \\
\text { Siswa }\end{array}$} & $\begin{array}{c}\text { Siklus } \\
\text { I }\end{array}$ & $\begin{array}{l}\text { Kriteri } \\
\mathbf{a}\end{array}$ & $\begin{array}{c}\text { Siklus } \\
\text { II }\end{array}$ & $\begin{array}{l}\text { Kriteri } \\
\mathbf{a}\end{array}$ \\
\hline 1. & Rasa suka siswa terhadap pelajaran & 3,6 & Tinggi & 3,6 & Tinggi \\
\hline 2. & $\begin{array}{l}\text { Partisipasi siswa dalam proses belajar } \\
\text { mengajar }\end{array}$ & 2,22 & Rendah & 2,5 & Sedang \\
\hline 3. & $\begin{array}{l}\text { Perhatian siswa selama proses belajar } \\
\text { mengajar }\end{array}$ & 3,4 & Tinggi & 3,4 & Tinggi \\
\hline 4. & Ketekunan belajar siswa & 2,25 & Rendah & 3,1 & Tinggi \\
\hline & Jumlah skor rata-rata & $\mathbf{2 , 9}$ & Sedang & $\mathbf{3 , 2}$ & Tinggi \\
\hline
\end{tabular}

Tabel 1 di atas menunjukkan bahwa skor rata-rata semangat belajar siswa mengalami peningkatan. Pada siklus I skor rata-rata semangat belajar siswa sebesar 2,9 dengan kriteria sedang, meningkat pada siklus II menjadi 3,2 dengan kriteria tinggi. Indikator Rasa suka terhadap pelajaran dan perhatian siswa selama proses belajar mengajar baik pada siklus I maupun siklus II sudah berada pada kriteria tinggi. Sedangkan indikator partisipasi siswa 
dalam proses belajar mengajar meningkat dari siklus I rendah meningkat menjadi sedang pada siklus II dan ketekunan belajar siswa pada kriteria rendah pada siklus I dan meningkat pada siklus II menjadi tinggi. Peningkatan semangat belajar siswa di atas, dapat dilihat pada gambar diagram berikut.

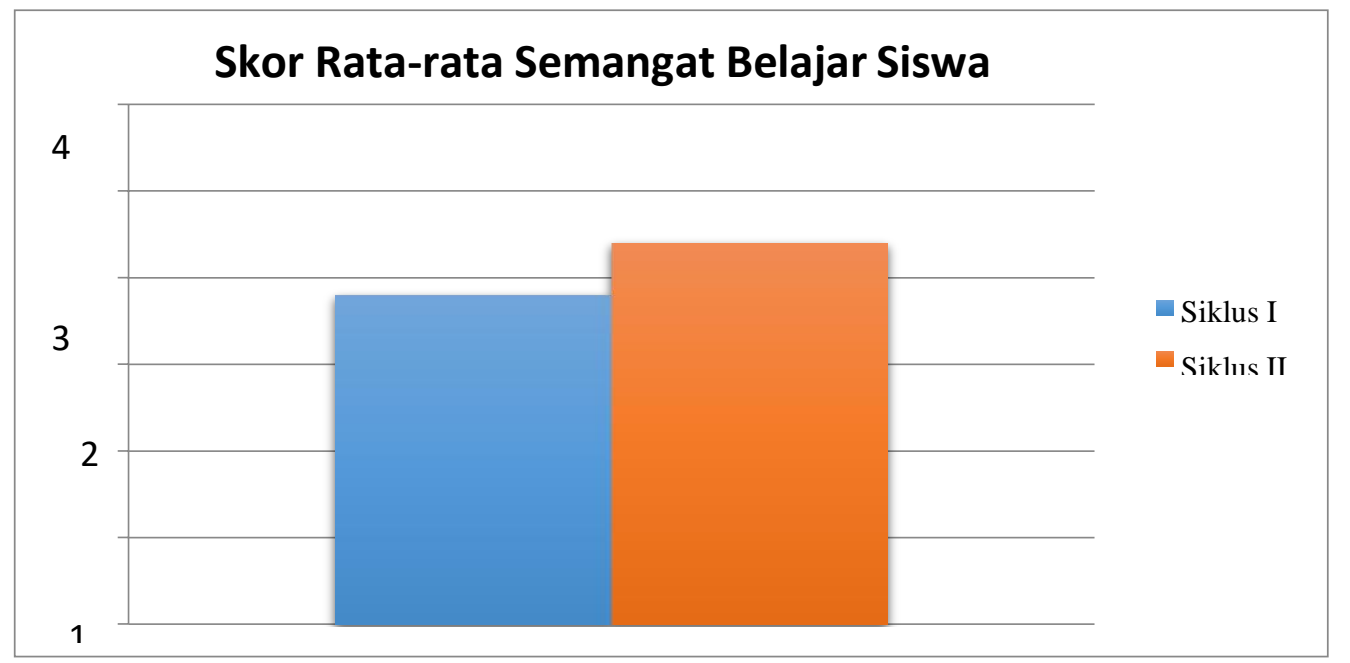

Gambar 1. Diagram peningkatan semangat belajar siswa Siklus I dan Siklus II

Gambar di atas menunjukkan bahwa adanya peningkatan skor rata-rata semangat belajar siswa dari siklus I sampai siklus II. Peningkatan skor rata-rata semangat belajar pada siklus II menunjukkan skor 3,2 dengan kriteria tinggi. Hal tersebut ditunjukkan dengan rasa suka siswa memperhatikan penjelasan guru dan perhatian siswa selama mengikuti pembelajaran dengan media Powtoon dengan baik.

Peningkatan semangat belajar di atas, ternyata juga diikuti dengan peningkatan hasil belajar siswa. Setelah dilakukan tes atau ulangan harian yang diadakan setiap akhir siklus, maka dapat dilihat rata-rata hasil belajar siswa seperti yang tampak pada tabel berikut:

Tabel 2 Rekapitulasi Hasil Belajar Siswa siklus I dan siklus II

\begin{tabular}{|c|c|c|c|c|c|c|c|c|c|c|c|}
\hline $\begin{array}{c}\text { Jum. } \\
\text { Siswa }\end{array}$ & $\begin{array}{l}\text { Nilai I } \\
\text { rata }\end{array}$ & Rata- & $\begin{array}{l}\text { Pen } \\
\text { ing } \\
\text { Kat }\end{array}$ & & $\begin{array}{l}\text { m } \\
\text { wa } \\
\text { tas }\end{array}$ & $\begin{array}{l}\text { Jun } \\
\text { tida } \\
\text { tunt }\end{array}$ & siswa & & $\begin{array}{l}\text { Intas } \\
\text { n } \\
\text { sikal }\end{array}$ & $\begin{array}{l}\text { Peni } \\
\text { ng }\end{array}$ & Ket \\
\hline \multirow[t]{2}{*}{35} & Sik. I & $\begin{array}{r}\text { Sik } \\
\text {.II }\end{array}$ & an & $\begin{array}{c}\text { Sik } \\
\text {.I }\end{array}$ & $\begin{array}{r}\text { Sik } \\
\text {.II }\end{array}$ & Sik.I & $\begin{array}{c}\text { Sik.I } \\
\text { I }\end{array}$ & $\begin{array}{c}\text { Sik. } \\
\text { I }\end{array}$ & Sik.II & $\begin{array}{l}\text { Kata } \\
\text { n }\end{array}$ & \\
\hline & 77,28 & 81,42 & 4,14 & 21 & 30 & 14 & 5 & $60 \%$ & $\begin{array}{c}85,71 \\
\%\end{array}$ & $\begin{array}{l}25,71 \\
\%\end{array}$ & Tuntas \\
\hline
\end{tabular}

Tabel 2 di atas menunjukkan bahwa hasil belajar dari siklus I sampai siklus II mengalami peningkatan. Pada siklus I nilai rata-rata siswa sebesar 77,28 dengan ketuntasan klasikal 60\%, pada siklus II nilai rata-ratanya naik menjadi 81,42 dengan ketuntasan klasikal $85,71 \%$. Tabel peningkatan hasil belajar di atas dapat digambarkan dalam diagram berikut: 


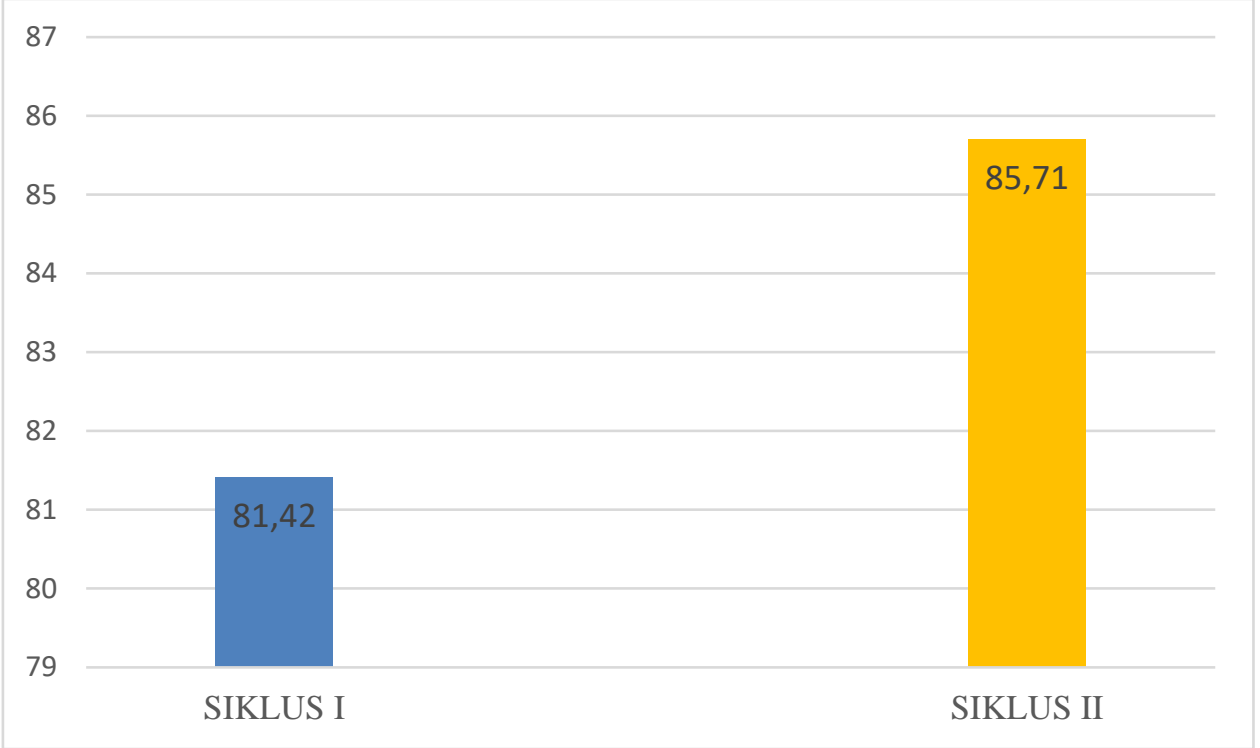

Gambar 2. Diagram Hasil Siklus I dan Siklus II

Berdasarkan gambar diagram analisis hasil belajar siswa di atas, dapat diketahui peningkatan hasil belajar siswa setelah dilakukan tindakan perbaikan dengan penggunaan media pembelajarn Powtoon pada materi pelajaran sistem perekonomian Indonesia. Nilai ratarata hasil belajar pada siklus I sebesar 77,28 dengan ketuntasan klasikal $60 \%$ meningkat menjadi 81,42 dengan ketuntasan klasikal sebesar 85,71\% pada siklus II. Peningkatan hasil belajar tersebut menunjukkan bahwa target penelitian telah tercapai yaitu siswa yang mendapatkan nilai lebih dari KKM yang ditentukan sekolah yaitu $>70$ lebih dari $75 \%$ dari seluruh siswa kelas XI.

\section{Pembahasan}

Hasil penelitian menunjukkan bahwa penggunaan media pembelajaran Powtoon dapat meningkatkan semangat belajar dan hasil belajar siswa pada pelajaran IPS materi sistem perekonomian Indonesia siswa kelas XI IPS 1 SMA Negeri 6 Tebo tahun ajaran 2018/2019. Dimana semangat belajar siswa meningkat dari kategori sedang menjadi tinggi. Hasil belajar siswa pada siklus 2 menunjukkan peningkatan hasil belajar dari 77,28 menjadi 81,42. Sehingga dapat disimpulkan bahwa hasil belajar siswa XI IPS 1 SMA Negeri 6 Tebo telah mencapai ketuntasan KKM sekolah yaitu 70 . Hal ini membuktikan bahwa hipotesis yang diajukan dalam penelitian ini terbukti.

Peningkatan semangat belajar siswa dapat dilihat pada proses pembelajaran menggunakan media pembelajaran Powtoon, siswa memanfaatkan waktu yang diberikan guru untuk kegiatan perhatian siswa yang terbukti dengan siswa dapat memahami materi yang diterangkan oleh guru dengan menggunakan media Powtoon, selanjutnya siswa memasukkan kata kunci materi pelajaran yang mereka temukan dalam media Powtoon sebagai catatan materi. Siswa memperhatikan media dan rasa suka siswa terhadap pelajaran, serta siswa dapat memahami dan mengerti pelajaran lebih baik. Sehingga muncul semangat partisipasi siswa dalam bertanya dan menjawab meskipun tidak semua siswa bertanya, hanya sebagian kecil siswa yang berpartisipasi.

Hal ini disebabkan karena siswa telah memahami materi yang dijelaskan oleh guru, sehingga siswa tidak perlu bertanya untuk memperjelas materi pelajaran. Peningkatan semangat belajar dan hasil belajar siswa juga diakui oleh guru pendidikan Ekonomi kelas XI IPS 1 sebagai pelaksana dari kegiatan perbaikan pembelajaran, berdasarkan hasil wawancara dengan guru yang menyatakan:

"Saya tidak menyangka anak-anak bisa berubah, biasanya ulangan harian siswa 50, 60 dan dapat 75 udah bagus, sekarang anak-anak banyak yang dapat nilai 75,80 Saya senang sekali. Jujur saya merasa mudah dan simpel saat mengajar dengan menggunakan media 
Powtoon ini yang baru saya ketahui. Saya ingin menggunakan media Powtoon ini untuk mengajar pada kelas lainnya dan pada pelajaran lainnya. Saya menilai semangat belajar siswa dapat dikatakan aktif meskipun tidak semua siswa." (Bapak Subhan, 28 tahun)

Berdasarkan pernyataan guru di atas media Powtoon mempermudah guru dalam pembelajaran siswa. Menurut Arsyad (2016:89), penggunaan media audio visual memegang peran yang sangat penting dalam proses belajar. Audio visual dapat pula menumbuhkan semangat siswa dan dapat memberikan hubungan antara isi materi pelajaran dengan dunia nyata. Peningkatan semangat belajar dan hasil belajar siswa, juga dirasakan langsung oleh siswa berdasarkan hasil wawancara kepada siswa yang memiliki hasil belajar tertinggi yaitu:

"iya kak, saya bersemangat, suka dan memperhatikan ketika guru menggunakan media Powtoon sebagai media pembelajaran di kelas saya. Karena media ini merupakan media yang baru bagi kami dari sebelumnya guru cuma menggunakan power point. Jadi ini membuat saya dan teman-teman memperhatikan guru mengajar." (Siswa L, 14 tahun).

Peningkatan hasil belajar siswa melalui penggunaan media pembelajaran Powtoon yang dialami oleh siswa XI IPS 1 SMA Negeri 6 Tebo yang memiliki hasil belajar jauh dari ketuntasan kelas hingga mencapai nilai ketuntasan kelas sebesar 86\% merupakan bukti bahwa pendapat Mayer dan Moreno (2002:20) yang menyatakan, dengan penggunaan media animasi dalam proses pembelajaran sangat membantu dalam meningkatkan efektifitas dan efesiensi proses pengajaran, serta hasil pembelajaran meningkat.

Berdasarkan hasil penelitian tindakan ini membuktikan bahwa hasil penelitian ini telah menjawab hipotesis tindakan yaitu penggunaan media pembelajaran Powtoon dapat meningkatkan semangat belajar dan hasil belajar siswa XI IPS 1 SMA Negeri 6 Tebo pada materi sistem perekonomian Indonesia semester genap tahun pelajaran 2018/2019. Akhirnya, dengan tercapainya tujuan penelitian dan terbuktinya hipotesis tindakan, maka penelitian ini dinyatakan berhasil.

\section{KESIMPULAN}

Berdasarkan hasil penelitian dan pembahasan, dapat disimpulkan bahwa penggunaan media Powtoon dapat meningkatkan semangat dan hasil belajar siswa pada materi sistem perekonomian Indonesia kelas XI IPS 1 SMA Negeri 6 Kabupaten Tebo Provinsi Jambi tahun pelajaran 2018/2019. Peningkatan semangat belajar siswa dapat dilihat dari skor rata-rata semangat sebelum tindakan yaitu 2,45 dengan kriteria rendah, pada siklus I mengalami peningkatan menjadi 2,9 dengan kriteria sedang, dan pada siklus II mengalami peningkatan kembali menjadi 3,2 dengan kriteria tinggi. Peningkatan hasil belajar siswa dapat dilihat dari rata-rata nilai ulangan harian siswa sebelum tindakan yaitu 72. Pada siklus I mengalami peningkatan rata-rata nilai ulangan harian menjadi 77,28. Kemudian mengalami peningkatan kembali pada siklus II dengan nilai rata-rata ulangan harian siswa menjadi 81,42. Peningkatan semangat dan hasil belajar siswa pada materi sistem perekonomian Indonesia siswa kelas kelas XI IPS 1 SMA Negeri 6 Kabupaten Tebo ini menunjukkan tercapainya tujuan penelitian penggunaan media Powtoon.

\section{DAFTAR PUSTAKA}

Adkhar, B. I. (2015). Pengembangan Media Video Animasi Pembelajaran Berbasis Powtoon pada Kelas 2 Mata Pelajaran Ilmu Pengetahuan Alam Disd Labschool Unnes (Doctoral dissertation, Universitas Negeri Semarang).

Chulsum, U. (2017). Pengaruh Lingkungan Keluarga, Kedisiplinan Siswa, Dan Motivasi Belajar Terhadap Hasil Belajar Ekonomi Siswa Di SMA Negeri 7 Surabaya. Jurnal ekonomi pendidikan dan Kewirausahaan, 5(1), 5-20.

Fajar, S. (2017). Pengaruh Penggunaan Media Powtoon Terhadap Hasil Belajar Siswa Pada Mata Pelajaran Ilmu Pengetahuan Sosial Terpadu: Kuasi Eksperimen Terhadap Siswa Kelas VII SMPN 25 Kota Bandung (Doctoral dissertation, Universitas Pendidikan Indonesia). 
Hermawati, N. W. M. (2012). Pengaruh model pembelajaran inkuiri terhadap penguasaan konsep biologi dan sikap ilmiah siswa SMA ditinjau dari minat belajar siswa. Jurnal Pendidikan dan Pembelajaran IPA Indonesia, 2(2).

Jihad dkk. 2012. Evaluasi pembelajaran. Yogyakarta: Multi Presindo.

Kartika, H. (2014). Pembelajaran matematika berbantuan software matlab sebagai upaya meningkatkan kemampuan komunikasi matematis dan minat belajar siswa SMA. JUDIKA (Jurnal Pendidikan Unsika), 2(1).

Khamid. 2015. Penggunaan Media Powtoon Dalam Pembelajaran Sejarah Untuk Meningkatkan Hasil Belajar Siswa Kelas X IPS 1 SMA Negeri 1 Slahung Ponorogo. Skripsi. Universitas Malang, Jawa Timur. Tidak dipublikasikan

Lestari, I. (2015). Pengaruh waktu belajar dan minat belajar terhadap hasil belajar matematika. Formatif: Jurnal Ilmiah Pendidikan MIPA, 3(2).

Maria. 2011. Penggunan Media Audio Visual Untuk Meningkatkan Minat Belajar Dan Hasil Belajar Siswa Kelas VIII F SMP Negeri 2 Balung Jember. Skripsi. Universitas Jember, Jawa Timur. Tidak dipublikasikan

Molstad, C. E., \&Karseth, B. (2016). National Curricula in Norway and Finland: The Role of Learning Outcomes. European Educational Research Journal, 15(3), 329-344.

Nemeth, J., \& Long, J. G. (2012). Assessing Learning Outcomes in U.S. Planning Studio Courses. Journal of Planning Education and Research, 32(4), 476-490.

Pangestu, A. D., Samparadja, H., \& Tiya, K. (2015). Pengaruh minat terhadap hasil belajar matematika siswa sma negeri 1 uluiwoi kabupaten kolaka timur. Jurnal Penelitian Pendidikan Matematika, 3(2), 17-26.

Prayuda, R., Thomas, Y., \& Basri, M. (2014). Pengaruh kemandirian belajar terhadap hasil belajar siswa pada mata pelajaran ekonomi di SMA. Jurnal Pendidikan dan Pembelajaran Khatulistiwa, 3(8).

Sunadi, L. (2013). Pengaruh motivasi belajar dan pemanfaatan fasilitas belajar terhadap prestasi belajar siswa pada mata pelajaran ekonomi kelas XI IPS di SMA Muhammadiyah 2 Surabaya. Jurnal Pendidikan Ekonomi (JUPE), 1(3).

Syaidah, U., Suyadi, B., \& Ani, H. M. (2018). Pengaruh kompetensi guru terhadap hasil belajar ekonomi di SMA Negeri Rambipuji Tahun Ajaran 2017/2018. Jurnal Pendidikan Ekonomi: Jurnal Ilmiah Ilmu Pendidikan, Ilmu Ekonomi dan Ilmu Sosial, 12(2), 185-191.

Widiasih, R., Widodo, J., \& Kartini, T. (2018). Pengaruh penggunaan media bervariasi dan motivasi belajar terhadap hasil belajar mata pelajaran ekonomi siswa kelas XI IPS SMA Negeri 2 Jember Tahun Pelajaran 2016/2017. JURNAL PENDIDIKAN EKONOMI: Jurnal Ilmiah Ilmu Pendidikan, Ilmu Ekonomi Dan Ilmu Sosial, 11(2), 103-107.

Young, M. E., Klemz, B. R., \& Murphy, J. W. (2003). Enhancing Learning Outcomes: The Effects of Instructional Technology, Learning Style, Instructional Methods and StudentBehavior.Journal ofMarketing Education, 25, 130. 